\title{
Introduction to the special issue "Green planet-400 million years of terrestrial floras. Papers in honour of JHA van Konijnenburg-van Cittert"
}

\author{
Evelyn Kustatscher • Lars W. van den Hoek Ostende • \\ Hans Kerp
}

Received: 8 April 2014 / Accepted: 9 April 2014 / Published online: 16 May 2014

(C) Senckenberg Gesellschaft für Naturforschung and Springer-Verlag Berlin Heidelberg 2014

Twelve publications by (former) students and colleagues of Johanna H.A. van Konijnenburg-van Cittert (Fig. 1) have been brought together in a special issue of Palaeobiodiversity and Palaeoenvironments. These deal with a wide variety of topics, ranging from fungal remains from the Lower Devonian Rhynie chert to three-dimensional reconstructions of Mesozoic conifer cones using advanced modern methods.

During her PhD research project, Johanna H.A. van Konijnenburg-van Cittert was one of the first who systematically studied in situ pollen from gymnosperm fructifications, thus bridging the gap between palynology and palaeobotany. After her $\mathrm{PhD}$ in 1970, she worked many years as an associate scientist at the Laboratory of Palaeobotany and Palynology in Utrecht, studying Mesozoic floras. She carried out much of her work at her home in Castricum, but visited the laboratory in Utrecht at least once a week, where she did the lab work and taught palaeobotany courses. In 1988, while retaining her position in Utrecht, Han started working as an associate scientist at the Naturalis Biodiversity Center, the Dutch national museum of natural history in Leiden, initially cataloguing the famous Jongmans collection, one of the world's largest and best

This article is a contribution to the special issue "Green planet -400 million years of terrestrial floras. Papers in honour of JHA van Konijnenburg-van Cittert

E. Kustatscher $(\bowtie)$

Naturmuseum Südtirol, Bindergasse 1, 39100 Bolzano/Bozen, Italy

e-mail: Evelyn.Kustatscher@naturmuseum.it

L. W. van den Hoek Ostende

Naturalis, PO Box 9517, 2300 RA Leiden, The Netherlands

H. Kerp

Forschungsstelle für Paläobotanik am Geologisch-Paläontologischen Institut, Westfälische Wilhelms-Universität Münster,

Heisenbergstraße 2, 48149 Münster, Germany collections of Carboniferous plant fossils. In 2003 she was appointed professor for pre-Quaternary palaeobotany at the University of Leiden, but she continued to teach in Utrecht. During her career Han has supervised several PhD students in both Leiden and Utrecht, but also in several other countries. She is one of the best specialists on Triassic and Jurassic floras, but Han also published on Permian, Cretaceous and Paleogene floras from various parts of the world, including the Arctic, Iran, Afghanistan and Indonesia. Her taxonomic work is based on careful microscopic observations. She has a very wide international network of collaborators, amateur palaeobotanists and professionals, which is reflected in her impressive publication record. At the time of her 70th birthday, she had authored more than 125 papers, and the number continues to grow. The publications brought together in this issue are a token of appreciation of her (former) students, friends and colleagues. Although they cover a wide variety of topics, they reflect only part of Han's interests-it quickly became evident that it would be impossible to include all aspects of her career in a single issue. The factor that binds all of these articles is that they are all based on the fossils of plants, and each paper tells its own part of the story of the evolution of terrestrial floras in the last 400 million years. It is the story of a Green Planet, to which Johanna van Konijnenburgvan Cittert has contributed so much. A contribution that has also been noted outside scientific circles. On the 26th April 2014, Han van Konijnenburg-van Cittert was decorated by royal decree as an Officer in the Order of Oranje-Nassau for her merits to science and society.

Michael Krings, Thomas N. Taylor, Edith L. Taylor, Hans Kerp and Nora Dotzler: "First record of a fungal "sporocarp" from the Lower Devonian Rhynie chert"

Krings, Taylor, Taylor, Kerp and Dotzler describe a number of spherical microfossils collectively referred to as fungal 


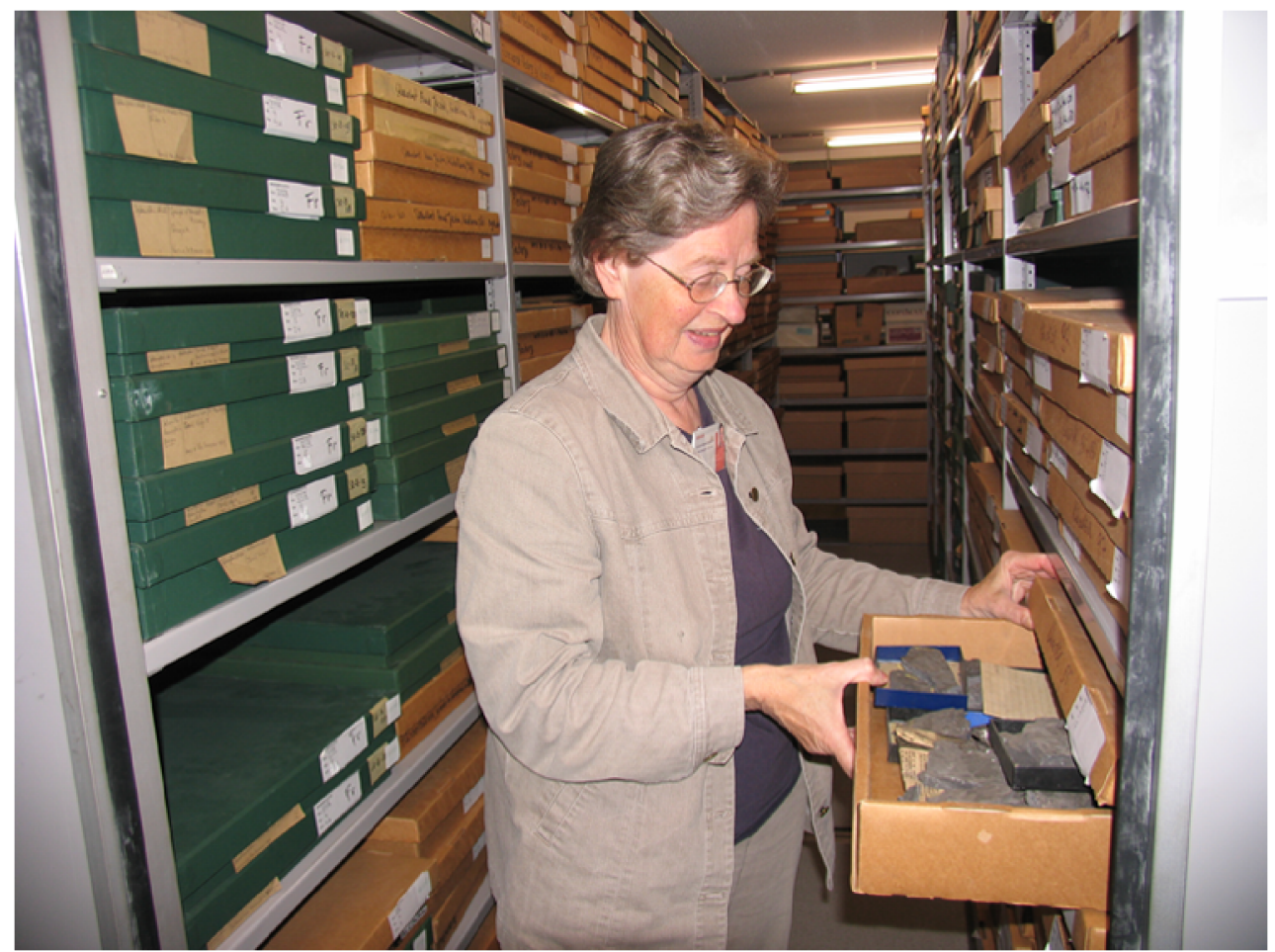

Fig. 1 Han (Johanna H.A.) van Konijnenburg-van Cittert in the palaeobotanical collection of Naturalis Biodiversity Center, Leiden (photograph taken by Evelyn Kustatscher)

"sporocarps". Sporocarps are well known from Carboniferous coal balls and chert deposits and from Triassic permineralised peats but these structures were unknown in pre-Carboniferous amd post-Triassic deposits. Therefore, the discovery of a fungal "sporocarp" from the Lower Devonian of Rhynie Chert is of particularly importance. The microfossil ( $<70 \mu \mathrm{m}$ in diameter) is composed of a spherical cavity sheathed by a prominent, twolayered hyphal investment. The interpretation as a fungal "sporocarp" is based on the morphological similarities to the Carboniferous "sporocarp" genus Mycocarpon. The new name Mycocarpon rhyniense $\mathrm{n}$. $\mathrm{sp}$. is proposed for what is currently the oldest evidence of fungal "sporocarps". (Palaeobio Palaeoenv 94(2). Doi 10.1007/s12549-013-0135-7)

\section{Annette E. Götz and Katrin Ruckwied: "Palynological records of the Early Permian postglacial climate amelioration (Karoo Basin, South Africa)"}

Götz and Ruckwied studied palynomorphs of the Permian coal-bearing formations of the South African Karoo Basin, demonstrating their crucial role in the study of the climate changes in Gondwana. The No. 2 coal seam of the Witbank coalfield, for example, documents a switch from icehouse to greenhouse conditions in the Early Permian. The postglacial fluvio-deltaic deposits are composed of coarse-grained to pebbly sandstones at the base. Upwards follow crossstratified medium- to coarse-grained sandstones and horizontally laminated sandstones and siltstones, while the sequence ends with fine-grained sediments and coal. The authors show how the palynofacies is generally characterised by a high amount of opaque phytoclasts, while the strata vary in palynomorph composition and in the amount and type, size and shape of plant debris. Götz and Ruckwied observed at the base of the coal seam a shift from a cold climate with fern wetland communities in the lowland alluvial plains and an upland conifer community to a cool-temperate cycad-like lowland vegetation and gymnosperm upland flora, thus documenting a shift from icehouse to greenhouse conditions. (Palaeobio Palaeoenv 94(2). Doi 10.1007/s12549-013-01348)

Evelyn Kustatscher, Matthias Franz, Carmen Heunisch, Mike Reich and Torsten Wappler: "Floodplain habitats of braided river systems: depositional environment, flora and fauna of the Solling Formation (Buntsandstein, Lower Triassic) from Bremke and Fürstenberg (Germany)"

Kustatscher, Franz, Heunisch, Reich and Wappler reconstruct the environmental setting during the deposition of the Middle Buntsandstein in the area of Bremke and Fürstenberg. This area yielded one of the earliest, European, well-diversified (at least 12 taxa) floras following the end-Permian mass extinction. Moreover, the authors document one of the earliest Triassic occurrences of insect herbivory after the end- 
Permian extinction worldwide, providing a rare glimpse into the third pulse of herbivore expansion. Integrated palaeobotanical, palaeontological and sedimentological studies enabled the authors to distinguish two different floodplain environmental settings during the deposition of the Middle Buntsandstein and to reconstruct the vegetation and the plantinsect interactions. This article shows just how important taphonomy and environmental settings were for the preservation of the plants during the deposition of the Buntsandstein. For Fürstenberg, the authors propose ephemeral ponds restricted to flood events, while they suggest that Bremke was characterised by perennial backswamps with a rich plant community. This study suggests that the scarcity of Buntsandstein floras is clearly related to taphonomical processes and not only to extreme environmental conditions under arid or semi-arid climates. (Palaeobio Palaeoenv 94(2). Doi: 10.1007/s12549-014-0161-0)

\section{Dieter Uhl, Christoph Hartkopf-Fröder, Ralf Littke and Evelyn Kustatscher: „Wildfires in the Late Palaeozoic and Mesozoic of the Southern Alps-The Anisian and Ladinian (Mid Triassic) of the Dolomites (Northern Italy)"}

Uhl, Hartkopf-Fröder, Littke and Kustatscher report the first evidence for palaeowildfires in the Alps during the Anisian and Ladinian. Charcoal remains were studied from two localities in the Dolomites (Northern Italy), i.e. Kühwiesenkopf/Monte Prà della Vacca (Pelsonian, upper Anisian) and Ritberg/Ju Rit (Longobardian, upper Ladinian). These remains help to fill a gap in the record of Triassic wildfires. Additionally, the charcoal reflectance values from Kühwiesenkopf were surprisingly high, allowing the authors to estimate a palaeo-wildfire temperature of approximately $650{ }^{\circ} \mathrm{C}$. (Palaeobio Palaeoenv 94(2). Doi 10.1007/s12549-014-0155-y)

\section{Sidney R. Ash: "Contributions to the Upper Triassic Chinle flora in the American southwest"}

Ash has dedicated his studies to the Upper Triassic Chinle Formation of the American southwest. In this paper, he presents three selected species of fossil gymnosperms from the Chinle Formation. The article includes an emended diagnosis of Lindleycladus arizonicus (Daugherty) comb. nov. and a description of Elatocladus puercoensis sp. nov. based on new material, Ash also re-describes the contentious plant fossil Dechellyia gormanii Ash, including the first evidence of insect predation (excisions and galls) on these leaves. (Palaeobio Palaeoenv 94(2). Doi: 10.1007/s12549-014-0150-3)
Wolfram M. Kürschner, Luke Mander and Jennifer C. McElwain: "A gymnosperm affinity for Ricciisporites tuberculatus Lundblad: implications for vegetation and environmental reconstructions in the Late Triassic"

Ricciisporites tuberculatus Lundblad is a heavily sculptured palynomorph, dispersed at maturity as tetrads, with a wide geographic distribution during the Norian-Rhaetian, especially in Europe. Unfortunately, it has not yet been found in situ. Kürschner, Mander and McElwain discuss its affinity and environmental implications based on its morphology and ultrastructure, thereby applying modern statistical methods. Morphological and ultrastructural studies of R. tuberculatus suggest a gymnospermous affinity. A re-evaluation of the Triassic-Jurassic boundary in East Greenland shows that the relative abundance of $R$. tuberculatus is similar to that of the Bennettitales Anomozamites and Pterophyllum. The authors suggest that $R$. tuberculatus may have been produced by a ruderal herbaceous gymnosperm. Principal component analyses show that the vectors of $R$. tuberculatus and those of the common pollen type Classopollis plot in opposite directions. The authors interpret this difference as an indication that the parent plants of $R$. tuberculatus and Classopollis (the Cheirolepidiaceae) may have had different ecological and/or climatological preferences. (Palaeobio Palaeoenv 94(2). Doi: 10.1007/s12549-014-0163-y)

\section{Christian Pott and Stephen McLoughlin: "Divaricate growth habit in Williamsoniaceae (Bennettitales): unravelling the ecology of a key Mesozoic plant group"}

Pott and McLoughlin discuss the growth habit of the bennettitalean family Williamsoniacae. These plants are interpreted as small-leaved shrubs or low-growing trees with densely interlaced stems bifurcating or trifurcating at broad angles, a growth habit known as divaricating. Apparently, this type of plant architecture has evolved independently in various modern plant families (18), most of which are found in New Zealand. There are various theories regarding the benefits of this growth habit type, such as protection against browsing, reaction to a dry, windy climate and/or optimisation of light harvesting. The authors show how this growth habit was likely most often used by the Williamsoniaceae in the mid-Mesozoic as an adaption to local environmental conditions, although defence against browsing tetrapods cannot be excluded completely. In this context, the authors see many characters that are convergent with members of the Banksiinae (Proteaceae), suggesting adaptation to open vegetation communities on nutrientdeficient soils. (Palaeobio Palaeoenv 94(2). Doi: 10.1007/ s12549-014-0157-9) 
Mihai E. Popa: "Early Jurassic Bennettitalean reproductive structures of Romania"

Bennettitales are important elements in the Early Jurassic floras of Romania and are represented by abundant vegetative remains (leaves, stems, roots) and reproductive organs. While the former are well known in the literature, information on the latter is still scarce. Popa describes for the first time all bennettitalean reproductive structures from the Steierdorf Formation (Hettangian-Sinemurian) of the Reșiţa Basin (Romania). The author describes 32 rock samples containing Williamsonia banatica Krasser emend., $W$. latecostata Semaka emend., Bennetticarpus sp. A and sp. B, Cycadolepis sp., Weltrichia alfredii Krasser emend., Weltrichia givulescui Popa 2001, Weltrichia johannae n. sp., Weltrichia antonii n. sp., Weltrichia steierdorfensis n. sp., Weltrichia sp. A and Weltrichia sp. B. In addition to the taxonomic study, the author also discusses a possible correlation to the vegetative remains of the same localities, such as the correlation of compression and cast fossils of Williamsonia latecostata, or the correlation of reproductive (Williamsonia banatica) and vegetative (Zamites schmiedelii) organs based on cuticular analysis. (Palaeobio Palaeoenv 94(2). Doi: 10.1007/s12549-0140165-9)

\section{Carole T. Gee: "Greater palaeobiodiversity in conifer seed cones in the Late Jurassic Morrison Formation of Utah, USA"}

Gee describes over sixty silicified seed cones with preserved internal anatomy from eleven localities in northeastern and southern Utah. The silicified cones were compared in size, gross morphology and internal construction and sorted into five new morphotypes of seed cone. With the help of macromorphology and computed tomography scans, the author attributed one morphotype to the Araucariaceae, one to the Pinaceae and one to the Cheirolepidiaceae, while two more could not yet be assigned to any family. Comparative size analysis based on volume calculations shows that four of the five cone types are much smaller than Mesozoic araucarian seed cones. Together with the previously described Araucaria delevoryasii Gee from Wyoming, the author was able to identify six morphotypes of seed cones representing at least three conifer families in Utah and Wyoming. These findings indicate that conifer forests or woodlands were a major type of vegetation in the Late Jurassic of the USA and were represented by various types of conifers. (Palaeobio Palaeoenv 94(2). Doi: 10.1007/s12549-0140160-1)
Jiří Kvaček: "Cunninghamites johannae, a new cupressoid conifer from the Cenomanian of the Czech Republic and its palaeoecological implications"

Jiří Kvaček describes a new species of conifer, Cunninghamites johannae sp. nov., from the Peruc-Korycany Formation (Cenomanian) of the Bohemian Cretaceous Basin (Czech Republic) in honour of Johanna H.A. van Konijnenburg-van Cittert. This conifer is characterised by long linear epistomatic leaves, arising from well-pronounced leaf cushions. The cuticle is characterised by monocyclic to incompletely dicyclic stomata arranged in two bands on the adaxial side of the leaf. According to the author, Cunninghamites johannae grew in a coniferdominated mesophytic plant assemblage. This unique palaeoenvironment is preserved and documented in the Lanšperk locality. (Palaeobio Palaeoenv 94(2). Doi: 10.1007/ s12549-014-0159-7)

Hylke F. Bosma and Johanna H.A. van Konijnenburg-van Cittert: "Revision of the Late Cretaceous conifer genus Moriconia"

Bosma and Van Konijnenburg-van Cittert revise the historical material of the Cretaceous conifer genus Moriconia. The authors distinguish Moriconia americana as having more robust and shorter branches than the type species M. cyclotoxon. The stratigraphic range also differs, with Moriconia cyclotoxon extending from the late Cenomanian to the early Maastrichtian and M. americana ranging from the Coniacian to the early Maastrichtian. Although the re-study of the material does not enable Bosma and Van Konijnenburgvan Cittert to resolve the botanical affinity, they do propose that the Cupressaceae is the most likely candidate, even though closely resembling genera, either fossil or extant, could not be identified. (Palaeobio Palaeoenv 94(2). Doi: 10. 1007/s12549-014-0158-8)

\section{Lutz Kunzmann: "On the fossil history of Pseudotsuga Carr. (Pinaceae) in Europe"}

Pseudotsuga is an accessory element in the Neogene vegetation in Central Europe. Kunzmann describes two species based on coalified seed cones, one species based on leaves and one species based on wood from the Miocene and Pliocene of Germany. The author extends the stratigraphic range of Pseudotsuga jechorekiae Czaja to the late early Miocene based on new seed cones from Wiesa (Germany) and emends the diagnosis of the Pliocene Pseudotsuga loehrii comb. nov. A critical revision of the leaf record re-assigns the leaf cuticles previously identified as "Pseudotsuga oceanines" to Tsuga or 
Nothotsuga; this brings into question the late Oligocene record of "Pseudotsuga oceanines". A comparison with extant species suggests an affinity with Asian species. Additionally, Kunzmann gives a palaeophytosociological, palaeoautecological and palaeoclimatic overview of the fossil species. (Palaeobio Palaeoenv 94(2). Doi: 10.1007/s12549-014-0156-x)

Acknowledgements First and foremost, all the editors thank the woman who made this all possible. Han van Konijnenburg-van Cittert has played an important role in all of our lives. This issue can only be but a small token of our appreciation in return. Thank you, Han.
We thank the Naturalis Biodiversity Center (NL), the National Herbarium of The Netherlands (NHN) and the Naturmuseum Südtirol (I) for the organisation of the symposium in April 2013 and the participants at the symposium for openly sharing their knowledge and new research findings covering 400 million years and all fossil plant groups. The authors all rose to the challenge of timely providing their contributions for this special issue in honour of Han, as did the reviewers in timely providing their constructive remarks on the submitted manuscripts.

Last but not least, we thank Peter Königshof and Sinje Weber for supporting our proposal to publish this collection of papers as a Special Issue of Palaeobiodiversity and Palaeoenvironments and for their help in all successive phases of this project. 